\title{
Correspondence
}

\section{Medvedev's Complaint}

SiR,-The excerpt from Zhores (that is, Jaurès) Medvedev's book (Nature, 227, 1197; 1970) strikes me as subtle communist propaganda. When I read in your editorial on page 1177 that a Russian scientist was not permitted to travel abroad, lost his job and was for some weeks kept in a psychiatric institution, I was duly incensed. Unfortunately, my indignation continued ebbing with every line of Medvedev's confession.

A few months ago, I was invited to give a lecture in France. I applied to the National Science Foundation for travel funds. After a long delay, my request was turned down. I did not complain to my Congressman, or to the senators from our state, or to the Head of the Foundation, or to the French Ambassador in Washington, or the US Ambassador in Paris, and so on. When the time of his lecture came, Medvedev read the latter to his friends; I did not. Why did I acquiesce in my defeat? Because the official who refused my application had, under the existing law, full right to reject my plea, as had the official who kept Professor Medvedev back.

It would be easy to clarify my position but, naturally, I do not want anyone to suffer from too much light.

$$
\text { Yours faithfully, }
$$

\section{J. J. BIKERMAN}

15810 Van Aken Boulevard,

Shaker Heights,

Ohio 44120 .

\section{Food for Thought}

SIR,-The rapidly growing science of nutrition is at a stage at which accurately characterized standard reference materials are urgently needed to provide a common basis for the great number and variety of studies that are being conducted in all parts of the world. Dietary control in animal experiments ${ }^{1}$ is only one of many applications to be made of such materials.

About twenty substances pertinent to work in nutrition are included among the standard substances issued by the World Health Organization and by various governmental and other agencies in different countries. These currently available reference materials are issued in specimens in the milligram-to-gram range; such quantities suffice for purposes of identification and analytical control, but are tos small for many applications in nutrition where gramto-kilogram quantities are required. Furthermore, the present materials are usually cortified for only a small number of constituents, whereas for many critical nutritional studies it is essential to know the content of many residual and trace constituents, particularly trace elements.

Immediate application can be foreseen for about eightyfive standard reference materials in the following categories: (1) essential nutrients in pure form; (2) basic food products of both natural and synthetic origin; (3) actual or simulated plant and animal tissues and fluids; (4) products involved in or resulting from plant or animal metabolism.

The expense of producing so many standard reference materials in large specimens would be so great that the operation would be feasible only if undertaken on a worldwide basis. For this reason I propose that concerned individuals, scientific societies, and standardizing agencies join in requesting the logical international agenciesthe World Health Organization and the Food and Agriculture Organization-jointly to undertake a programme of International Standard Reference Materials. I shall be glad to furnish specific suggestions regarding such a programme to anyone who may be interested.

\section{Yours faithfully,}

\section{Archibald T. McPherson}

4005 Cleveland Street,

Kensington, Maryland 20795.

${ }^{1}$ Nutrition Reviews, 27, 299 (October 1969).

\section{Misleading Units}

Sir,-In a review of mycotoxins (Economie et Médecine Animales, 11, 75; 1970) C. W. Hesseltine gives concentrations of mycotoxins "par billion". I am convinced that they should be written "par milliard". For example, the sentence: "La limite de sensibilité des analyses utilisées s'élevait à 2-5 par billion d'aflatoxine", was almost certainly understood by Hesseltine in the United States as $2-5$ per $10^{9}$, whereas in most of the world this French sentence would be read as $2-5$ per $10^{12}$. Therefore I would like to appeal to toxicologists, and in particular to American colleagues, not to use the misleading term parts per billion (p.p.b.). It is possible to express the same concentrations in parts per million (p.p.m.), which is equally understandable to toxicologists from all over the world.

\section{Yours faithfully,}

\section{Teodor Juszkiewicz}

Department of Pharmacology and Toxicology, Veterinary Research Institute, Puławy, Poland.

\section{Radiation Hazards}

SIR,-Baines (Nature, 227, 869; 1970) quotes some of our data for Australia and New Guinea to support his views on radiation hazards to South Pacific communities. The quotation, however, is hardly relevant. In fact the results of our measurements on fallout from nuclear weapons tests in French Polynesia--the source of Baines's concernhave been assessed by the Australian National Radiation Advisory Committee and found to have no significance as a hazard to health of the Australian community ${ }^{1}$.

Measurements on shorter-lived fission products in fallout over Australia and New Guinea ${ }^{2}$ following the French nuclear weapons tests of 1966,1967 and 1968 indicate that:

(1) the highest $\gamma$-radiation dose to the whole body estimated from measured fallout from all tests in the three series was $3 \cdot 3 \mathrm{mrad}$;

(2) the highest radiation dose to thyroid for young children due to ${ }^{131} \mathrm{I}$ in milk consumed during any 12 month period between 1966 and 1968 was estimated at 226 mrad.

As we pointed out when reporting the measurements, these radiation doses are not only the highest but are also upper limits. Thus weathering, shielding and other effects would reduce whole body doses by a factor of 3 to 5 , while decay of ${ }^{131} \mathrm{I}$ before the milk is consumed, and other factors, would result in substantially lower thyroid doses. In any case, these upper limits on estimated dose are far less than dose levels which would be expected to be of biological significance ${ }^{3}$. Although measurements are still in progress on fallout in Australia from the 1970 serics of tests in Polynesia, the data accumulated up to the present indicate 